\title{
Update on Recommendations for the Clinical Management of Hepatitis C in Iran 2017
}

\author{
Seyed Moayed Alavian, ${ }^{1,2,{ }^{*}}$ and Heidar Sharafi, \\ ${ }^{1}$ Baqiyatallah Research Center for Gastroenterology and Liver Diseases, Baqiyatallah University of Medical Sciences, Tehran, IR Iran \\ ${ }^{2}$ Middle East Liver Disease (MELD) Center, Tehran, IR Iran \\ "Corresponding author: Seyed Moayed Alavian, Middle East Liver Diseases (MELD) Center, No. 178, Cross Shadab, Sepahbod Gharani Street, P.O. Box: 14155/3651, Tehran, IR Iran. \\ Tel: +98-2188945186, Fax: +98-2188945188, E-mail: alavian@thc.ir
}

Received 2017 November 11; Accepted 2017 November 15.

Keywords: Hepatitis C, Therapy, Iran

\section{Background}

Treatment of the hepatitis C virus (HCV) has greatly transformed through recent decades (1). Nowadays, the $\mathrm{HCV}$ infection is a curable disease with introduction of HCV direct-acting antiviral (DAA) agents (2-4). Since 2015, various all-oral regimens approved for treatment of $\mathrm{HCV}$ with introduction of new treatment regimens in 2017 including sofosbuvir/velpatasvir/voxilaprevir (SOF/VEL/VOX) and glecaprevir/pibrentasvir (GLE/PIB). Hopefully, the generic DAAs including SOF, sofosbuvir/ledipasvir fixed dose combination (SOF/LDV), daclatasvir (DCV) and sofosbuvir/daclatasvir fixed dose combination (SOF/DCV) are available in Iran since $2016(5,6)$. With availability of these generic DAAs, Iranian healthcare system decided to eliminate hepatitis $C$ in the country with an estimation of 186000 infected patients $(7,8)$. It has been estimated that 4500 patients with the HCV infection were treated for HCV in 2015 and the number of treated patients increased to 6200 in 2016 (based on the unpublished data). The number of treatment uptakes should increase to 18000 in 2018 - 2030 annually to achieve the goal of HCV elimination in Iran by 2030 (8).

In 2016, Iran hepatitis network(IHN) prepared the "Recommendations for the Clinical Management of Hepatitis C in Iran: A Consensus-Based National Guideline" based on the availability of evidences and generic DAAs in Iran (9). However, based on the rapid evolution of the published evidences in literature and also availability of new treatment regimens, there is a great need to update the treatment protocol in Iran. Moreover, with treating more than 12000 cases with SOF/LDV or SOF/DCV or SOF + DCV in 2015 2017 , it is expected to observe more than 300 cases of treatment failure, which they need retreatment with another regimen. Hopefully, the new treatment regimen of sofosbuvir/velpatasvir fixed dose combination (SOF/VEL) is now available as a generic drug in Iran. In this editorial we de- cided to present an update on recommendations for the clinical management of hepatitis $\mathrm{C}$ in Iran.

\section{Update on Treatment of HCV Genotype 1 and 4 Infec- tions}

Recent real-world studies on treatment of HCV genotype 1 (HCV-1) infection demonstrated that 12 weeks of SOF/LDV, SOF + DCV or SOF/VEL is efficient for treatment of the HCV-1 infection in non-cirrhotic patients without previous history of HCV antiviral therapy (2, 5, 10-12). Treatment with suboptimal regimen of SOF + Pegylated Interferon (PegIFN) + RBV with around 90\% efficacy in HCV-1 is not recommended anymore (3). In HCV-1 infected patients with a previous history of PegIFN + RBV therapy and/or cirrhosis (child A), intensification of 12 weeks of SOF/LDV or $\mathrm{SOF}+\mathrm{DCV}$ with adding RBV is recommended, however, the latter groups can be treated with 12 weeks of SOF/VEL without addition of $\operatorname{RBV}(2,11,12)$. Moreover, decompensated cirrhosis (child $\mathrm{B}$ and $\mathrm{C}$ ) patients with HCV-1 infection can be treated for 24 weeks of SOF/LDV, SOF + DCV or SOF/VEL with addition of $\operatorname{RBV}(4,6,11,13)$. However, in RBV-intolerant cases, treatment can be extended to 24 weeks of SOF/LDV, SOF + DCV, or SOF/VEL without RBV. Based on the availability of SOF/VEL in Iran, HCV-1 infected patients with a history of IFN-free DAA-therapy can be retreated with 24 weeks of SOF/VEL with addition of RBV and around a 95\% chance of treatment success (14). The recommendations for treatment of HCV-G1 and -G4 are summarized in Table 1.

\section{Update on Treatment of HCV Genotype 3 Infection}

Non-cirrhotic, treatment naïve patients with HCV-3 can be treated with 12 weeks of SOF + DCV or SOF/VEL $(11,15)$. Treatment of non-cirrhotic HCV-3 infected patients with history of PegIFN + RBV therapy should be intensified by 


\begin{tabular}{|c|c|c|c|}
\hline $\begin{array}{l}\text { Treatment Naïve Patients without } \\
\text { Cirrhosis }\end{array}$ & $\begin{array}{c}\text { DAA-naïve Patients with } \\
\text { Compensated Cirrhosis }{ }^{\mathrm{a}} \text { (Child A) } \\
\text { and/or History of PegIFN+RBV } \\
\text { Therapy }\end{array}$ & $\begin{array}{l}\text { DAA-naïve Patients with } \\
\text { Decompensated Cirrhosis (Child B } \\
\text { or C) }\end{array}$ & DAA-experienced Patients \\
\hline $\begin{array}{l}\text { A. Daily DCV }(60 \mathrm{mg})+\text { Daily SOF ( } 400 \\
\mathrm{mg}) \text { for } 12 \text { weeks }\end{array}$ & $\begin{array}{l}\text { A. Daily DCV }(60 \mathrm{mg})+\text { Daily SOF ( } 400 \\
\mathrm{mg}) \text { with Daily RBV }(1000-1200 \mathrm{mg}) \text { for } \\
12 \text { weeks }^{\mathrm{b}}\end{array}$ & $\begin{array}{l}\text { A. Daily DCV }(60 \mathrm{mg})+\text { Daily SOF ( } 400 \\
\mathrm{mg}) \text { with Daily RBV }(1000-1200 \mathrm{mg}) \text { for } \\
24 \text { weeks }^{\mathrm{b}}\end{array}$ & $\begin{array}{c}\text { A. Daily VEL (100 mg) + Daily SOF } \\
\text { (400mg) with Daily RBV (1000-1200 } \\
\text { mg) for } 24 \text { weeks }{ }^{\text {b }}\end{array}$ \\
\hline $\begin{array}{l}\text { B. Daily LDV }(90 \mathrm{mg})+\text { Daily SOF } \\
(400 \mathrm{mg}) \text { for } 12 \text { weeks }\end{array}$ & $\begin{array}{l}\text { B. Daily LDV }(90 \mathrm{mg})+\text { Daily SOF } \\
(400 \mathrm{mg}) \text { with Daily RBV }(1000-1200 \\
\text { mg) for } 12 \text { weeks }^{\text {b }}\end{array}$ & $\begin{array}{l}\text { B. Daily LDV }(90 \mathrm{mg})+\text { Daily SOF } \\
\text { (400mg) with Daily RBV }(1000-1200 \\
\text { mg) for } 24 \text { weeks }\end{array}$ & \\
\hline $\begin{array}{l}\text { C. Daily VEL }(100 \mathrm{mg})+\text { Daily SOF }(400 \\
\mathrm{mg}) \text { for } 12 \text { weeks }\end{array}$ & $\begin{array}{l}\text { C. Daily VEL (100 mg) + Daily SOF (400 } \\
\text { mg) for } 12 \text { weeks }\end{array}$ & $\begin{array}{c}\text { C. Daily VEL (100 mg) + Daily SOF } \\
\text { (400mg) with Daily RBV (1000-1200 } \\
\text { mg) for } 24 \text { weeks }{ }^{\mathrm{b}}\end{array}$ & \\
\hline
\end{tabular}

Abbreviations: DCV, daclatasvir; LDV, ledipasvir; PegIFN, pegylated interferon; RBV, ribavirin; SOF, sofosbuvir; VEL, velpatasvir.

${ }^{a}$ Including patients with pre-cirrhosis (F3 - F4).

${ }^{b} 24$ weeks without $R B V$ in cases with RBV intolerance or contraindication.

adding RBV to 12 weeks of SOF + DCV or SOF/VEL $(15,16)$. Cirrhotic (child A) patients with HCV-3 infection should be treated with 24 weeks of SOF + DCV + RBV and 12 weeks of SOF/VEL+RBV $(15,16)$. Furthermore, decompensated cirrhosis (child B and C) patients with HCV-3 infection should be treated 24 weeks of SOF + DCV or SOF/VEL with addition of RBV $(13,16)$. However, in RBV-intolerant cases, treatment can be extended to 24 weeks of SOF + DCV or SOF/VEL without RBV. Based on the availability of SOF/VEL in Iran, HCV3 infected patients with history of IFN-free DAA-therapy can be retreated with 24 weeks SOF/VEL with addition of RBV and around a $80 \%$ chance of treatment success (14). The recommendations for treatment of HCV-G3 are summarized in Table 2 .

\section{Is it Important to Genotype HCV Prior to Treatment?}

For around 20 years, HCV genotyping was the routine laboratory evaluation prior to initiation of HCV treatment with IFN-based therapies. Patients with HCV-1 were classified as "hard-to-treat" and needed intensified treatment with IFN-based treatments in terms of treatment duration. On the other hand, patients with HCV-3 needed a shorter therapy duration and achieved a higher rate of treatment success with IFN-based therapies than patients with HCV1 infection $(17,18)$. With introduction of DAAs the role of HCV genotyping in clinical management of hepatitis $C$ has been faded. With availability of SOF + DCV regimen in Iran, patients with HCV infection could be treated with this regimen without the result of HCV genotyping, however, if the HCV-3 infected patients harbor cirrhosis, they would need an intensified therapy using 24 weeks of SOF + DCV + RBV (Table 2). With availability of SOF/VEL regimen in Iran, it seems that HCV genotyping can be excluded from the clinical management of HCV infection if we add RBV to treat- ment of all patients with cirrhosis and/or previous history of treatment with PegIFN + RBV.

\section{Update on Treatment of HCV in Patients with Chronic Renal Failure}

Patients with renal failure or on hemodialysis are at a higher risk for HCV infection and therefore, treatment of these patients needs special attention. The best strategy for these patients without liver cirrhosis is sending them to renal transplantation. Treatment of HCV infection should be postponed to 3 months after transplantation (19). According to the guidelines "timing of HCV treatment in relation to kidney transplantation (before vs. after)" should be based on donor type (living vs. deceased donor), waitlist times by donor type, center-specific policies for using kidneys from HCV-infected deceased donors, HCV genotype, and severity of liver fibrosis. In non-cirrhotic patients, that are Metavir Fo - F3, kidney transplant candidacy and graft access should dictate timing of therapy. The drug interactions, to be mindful of significantly increased Cmax Simeprevir (SMV) with cyclosporine, significantly increased calcineurin inhibitor levels with SMV and DSV/OBV/PTV/ritonavir and the protease inhibitors with antifungals. In Iran, we do not have access to the latter DAAs and there are no significant interactions with the available HCV antiviral regimen in Iran. Patients with both decompensated liver disease and end-stage renal disease (ESRD) who are considered transplant candidates must be listed for a combined liver/kidney transplant. Antiviral therapy in this setting should be postponed to the post-transplant setting.

Recently, renal safety of new DAA regimens in HCV patients with comorbid ESRD is clear. The FDA has not 
Table 2. Treatment of Patients with Hepatitis C Virus Genotype 3 Infection

\begin{tabular}{|c|c|c|c|c|}
\hline $\begin{array}{l}\text { Treatment Naïve Patients } \\
\text { without Cirrhosis }\end{array}$ & $\begin{array}{c}\text { DAA-naïve, } \\
\text { PegIFN+RBV-experienced } \\
\text { Patients without Cirrhosis }\end{array}$ & $\begin{array}{l}\text { DAA-naïve Patients with } \\
\text { Cirrhosis }^{\mathbf{a}}(\text { Child A) } \pm \\
\text { History of PegIFN }+ \text { RBV } \\
\text { Therapy }\end{array}$ & $\begin{array}{l}\text { DAA-naïve Patients with } \\
\text { Decompensated Cirrhosis } \\
\text { (Child B or C) }\end{array}$ & DAA-experienced Patients \\
\hline $\begin{array}{l}\text { A. Daily DCV }(60 \mathrm{mg})+\text { Daily } \\
\text { SOF }(400 \mathrm{mg}) \text { for } 12 \text { weeks }\end{array}$ & $\begin{array}{l}\text { A. Daily DCV (60 mg) + Daily } \\
\text { SOF }(400 \mathrm{mg}) \text { with Daily RBV } \\
(1000-1200 \mathrm{mg}) \text { for } 12 \text { weeks }\end{array}$ & $\begin{array}{l}\text { A. Daily DCV (60 mg) + Daily } \\
\text { SOF }(400 \mathrm{mg}) \text { with Daily RBV } \\
(1000-1200 \mathrm{mg}) \text { for } 24 \text { weeks }\end{array}$ & $\begin{array}{l}\text { A. Daily DCV }(60 \mathrm{mg})+\text { Daily } \\
\text { SOF }(400 \mathrm{mg}) \text { with Daily RBV } \\
(1000-1200 \mathrm{mg}) \text { for } 24 \text { weeks }\end{array}$ & $\begin{array}{l}\text { A. Daily VEL (100 mg) + Daily } \\
\text { SOF (400mg) with Daily RBV } \\
(1000-1200 \mathrm{mg}) \text { for } 24 \text { weeks }\end{array}$ \\
\hline $\begin{array}{l}\text { B. Daily VEL }(100 \mathrm{mg})+\text { Daily } \\
\text { SOF ( } 400 \mathrm{mg}) \text { for } 12 \text { weeks }\end{array}$ & $\begin{array}{l}\text { B. Daily VEL (100 mg) + Daily } \\
\text { SOF }(400 \mathrm{mg}) \text { with Daily RBV } \\
(1000-1200 \mathrm{mg}) \text { for } 12 \text { weeks }\end{array}$ & $\begin{array}{l}\text { B. Daily VEL (100 mg) + Daily } \\
\text { SOF }(400 \mathrm{mg}) \text { with Daily RBV } \\
(1000-1200 \mathrm{mg}) \text { for } 12 \text { weeks }\end{array}$ & $\begin{array}{l}\text { B. Daily VEL (100 mg) + Daily } \\
\text { SOF (400 mg) with Daily RBV } \\
(1000-1200 \mathrm{mg}) \text { for } 24 \text { weeks }\end{array}$ & \\
\hline
\end{tabular}

Abbreviation: DCV, daclatasvir; PegIFN, pegylated interferon; RBV, ribavirin; SOF, ledipasvir; VEL, velpatasvir.

${ }^{a}$ Including patients with pre-cirrhosis (F3-F4).

${ }^{b} 24$ weeks without RBV in cases with RBV intolerance or contraindication.

yet approved SOF-based therapy, however, in Iranian experiences (Unpublished), these patients tolerated SOF + DCV and SOF/LDV therapies. Nonetheless, this limited data evaluating SOF-based regimens is inadequate to provide stronger guidance on its potential role in clinical practice. We need to multicenter cohort studies. Unfortunately, DSV/OBV/PTV/ritonavir cannot be administered in advanced liver diseases and Grazoprevir/Elbasvir regimen is not available in Iran.

In conclusion, with this update on clinical management of HCV infection in Iran, the treatment strategy is more feasible and less complex than before and more HCV patients can uptake treatment with active patient finding and integration of HCV treatment in primary public health system. The patients with failure following IFN-free DAA regimens can be treated in liver-specialized clinics using intensified SOF/VEL regimen.

\section{Footnotes}

Authors' Contribution: All authors contributed equally in preparation of this editorial.

\section{Conflict of interest: None.}

Funding/Support: None.

\section{References}

1. Hesamizadeh K, Sharafi H, Rezaee-Zavareh MS, Behnava B, Alavian SM. Next Steps Toward Eradication of Hepatitis C in the Era of Direct Acting Antivirals. Hepat Mon. 2016;16(4):37089. doi: 10.5812/hepatmon.37089. [PubMed: 27275164].

2. Rezaee-Zavareh MS, Hesamizadeh K, Behnava B, Alavian SM, GholamiFesharaki M, Sharafi H. Combination of Ledipasvir and Sofosbuvir for Treatment of Hepatitis C Virus Genotype 1 Infection: Systematic Review and Meta-Analysis. Ann Hepatol. 2017;16(2):188-97. doi 10.5604/16652681.1231562. [PubMed: 28233739].

3. Dolatimehr F, Karimi-Sari H, Rezaee-Zavareh MS, Alavian SM, Behnava $\mathrm{B}$, Gholami-Fesharaki M, et al. Combination of sofosbuvir, pegylatedinterferon and ribavirin for treatment of hepatitis $C$ virus genotype
1 infection: a systematic review and meta-analysis. Daru. 2017;25(1):11. doi: 10.1186/s40199-017-0177-x. [PubMed: 28427463].

4. Rezaee-Zavareh MS, Hesamizadeh K, Sharafi H, Alavian SM. Treatment of hepatitis c infection with direct-acting antiviral agents in livertransplant patients: A systematic review and meta-analysis. Hepat Mon. 2017;17(6).

5. Sharafi H, Nikbin M, Alavian SH, Behnava B, Alavian SM. Efficacy and safety of generic sofosbuvir/ledipasvir fixed-dose combination in iranian patients with chronic hepatitis $\mathrm{C}$ virus infection. Hepat Mon. 2017;17(6) doi: 10.5812/hepatmon.12216.

6. Merat S, Sharifi AH, Haj-Sheykholeslami A, Poustchi H, Fattahi B, Nateghi-Baygi A. The efficacy of 12 weeks of sofosbuvir, daclatasvir, and ribavirin in treating hepatitis c patients with cirrhosis, genotypes 1 and 3. Hepat Mon. 2017;17(1):44564.

7. Hajarizadeh B. Generic direct acting antiviral treatment: The first step towards elimination of hepatitis C in Iran. Hepat Mon. 2017;17(1):45788.

8. Hajarizadeh B, Razavi-Shearer D, Merat S, Alavian SM, Malekzadeh R, Razavi H. Liver Disease Burden of Hepatitis C Virus Infection in Iran and the Potential Impact of Various Treatment Strategies on the Disease Burden. Hepat Mon. 2016;16(7):37234. doi: 10.5812/hepatmon.37234. [PubMed: 27642346].

9. Alavian SM, Hajarizadeh B, Bagheri Lankarani K, Sharafi H, Ebrahimi Daryani N, Merat S, et al. Recommendations for the Clinical Management of Hepatitis C in Iran: A Consensus-Based National Guideline. Hepat Mon. 2016;16(8):40959. doi: 10.5812/hepatmon.guideline. [PubMed: 27799966].

10. Curry MP, Tapper EB, Bacon B, Dieterich D, Flamm SL, Guest L, et al. Effectiveness of 8-or 12-weeks of ledipasvir and sofosbuvir in real-world treatment-naive, genotype 1 hepatitis $\mathrm{C}$ infected patients. Aliment Pharmacol Ther. 2017;46(5):540-8. doi: 10.1111/apt.14204. [PubMed: 28691377].

11. Alavian SM, Rezaee-Zavareh MS. Daclatasvir-based Treatment Regimens for Hepatitis C Virus Infection: A Systematic Review and MetaAnalysis. Hepat Mon. 2016;16(9):41077. doi: 10.5812/hepatmon.41077. [PubMed: 27826322].

12. Feld JJ, Jacobson IM, Hezode C, Asselah T, Ruane PJ, Gruener N, et al. Sofosbuvir and Velpatasvir for HCV Genotype 1, 2, 4, 5, and 6 Infection. NEngl J Med. 2015;373(27):2599-607. doi: 10.1056/NEJMoa1512610. [PubMed: 26571066].

13. Curry MP, O'Leary JG, Bzowej N, Muir AJ, Korenblat KM, Fenkel JM, et al. Sofosbuvir and Velpatasvir for HCV in Patients with Decompensated Cirrhosis. N Engl J Med. 2015;373(27):2618-28. doi: 10.1056/NEJMoa1512614. [PubMed: 26569658].

14. Gane EJ, Shiffman ML, Etzkorn K, Morelli G, Stedman CAM, Davis MN, et al. Sofosbuvir-velpatasvir with ribavirin for 24 weeks in hepatitis 
$C$ virus patients previously treated with a direct-acting antiviral regimen.Hepatology. 2017;66(4):1083-9. doi:10.1002/hep.29256. [PubMed: 28498551].

15. Foster GR, Afdhal N, Roberts SK, Brau N, Gane EJ, Pianko S, et al. Sofosbuvir and Velpatasvir for HCV Genotype 2 and 3 Infection. N Engl J Med. 2015;373(27):2608-17. doi: 10.1056/NEJMoa1512612. [PubMed: 26575258].

16. Zanaga LP, Miotto N, Mendes LC, Stucchi RS, Vigani AG. Treatment of hepatitis $C$ virus genotype 3 infection with direct-acting antiviral agents. BrazJ Med Biol Res. 2016;49(11):5504.

17. Keshvari M, Alavian SM, Behnava B, Pouryasin A, Craig JC, Sharafi H.
Impact of IFNL4 rs12979860 and rs8099917 polymorphisms on response to Peg-Interferon-alpha and Ribavirin in patients with congenital bleeding disorder and chronic hepatitis C. J Clin Lab Anal. 2017;31(4) doi: 10.1002/jcla.22063. [PubMed: 27735085].

18. Behnava B, Sharafi H, Keshvari M, Pouryasin A, Mehrnoush L, Salimi S, et al. The Role of Polymorphisms Near the IL28B Gene on Response to Peg-Interferon and Ribavirin in Thalassemic Patients With Hepatitis C. Hepat Mon. 2016;16(1):32703. doi: 10.5812/hepatmon.32703. [PubMed: 27110259].

19. Alavian SM, Hepatitis C. Chronic renal failure, control is possible. Hepat Mon. 2006;6(2):51-552. 